\title{
T15 - Aguas residuales y contaminación del lago de Amatitlán: Villa Canales y Villa Nueva (2005-2014)
}

\author{
Luis F. Olayo \\ Centro de Estudios Urbanos (CEUR), Universidad de San Carlos de Guatemala (USAC)
}

*Autor al que se dirige la correspondencia: arquitectolayo@yahoo.com

\section{Resumen}

T a contaminación y destrucción del lago de Amatitlán es un problema ambiental actual y de gran magnitud en Lel Área Metropolitana de la Ciudad de Guatemala, un fenómeno antrópico que crece aceleradamente, derivado del crecimiento demográfico y urbano que experimentan los lugares poblados de los 14 municipios que se localizan en la cuenca del lago de Amatitlán. La vivienda urbana -que se cuantifica por miles- es una de las fuentes productoras de las aguas residuales domiciliares que se depositan en el citado lago desde el traslado y asentamiento de la ciudad de Guatemala de la Asunción al Valle de la Ermita en el año de 1776 hasta el año 2016 (240 años), las que nunca han recibido un tratamiento apropiado; esta tendencia hará que en el corto plazo, el lago se pierda, convirtiéndose en un pantano insalubre que hará inhabitables sus tierras adyacentes. Mediante estimaciones de población urbana municipal y datos recientes de la cantidad de viviendas construidas en las áreas urbanas de los municipios de Villa Canales y Villa Nueva en el período 2005-2014, se estimó la producción de aguas residuales domiciliares (caudales o volúmenes), útiles para ilustrar y dimensionar este problema, débilmente visibilizado, considerado y valorado por la población, la iniciativa privada e instituciones del estado -municipalidades, instituciones y ministerios-, involucradas en este problema.

Palabras claves: Crecimiento urbano, cuenca, medio ambiente, recursos hídricos, urbanización

\begin{abstract}
$\mathrm{P}$ ollution and destruction of Amatitlan lake is a current and large-scale environmental problem in the Metropolitan area of Guatemala City, an anthropic phenomenon that is growing rapidly, derived from demographic and urban growth experienced by populated places of 14 municipalities that are located in the basin Amatitlan Lake. Urban housing, quantified by thousands, is one of the producing sources of domiciliary sewage deposited in the lake since the transfer and settlement of Guatemala City to the Ermita Assumption Valley in 1776 to 2016 (240 years), who have never received proper treatment, this trend will in the short term cause the lake lost, becoming an unhealthy swamp with inhabitable adjacent lands. Estimates by municipal urban population and recent data of the number of homes built in urban areas of the municipalities of Villa Canales and Villa Nueva in the period 2005-2014, the production of domiciliary wastewater (flow rates or volumes) was estimated, useful and size to illustrate this problem, weakly visible, considered and valued by the population, the private sector and state institutions -municipalities, state institutions and ministries-, involved in this problem.
\end{abstract}

Keywords: Urban growth, basin, environment, water resources, urbanization. 